
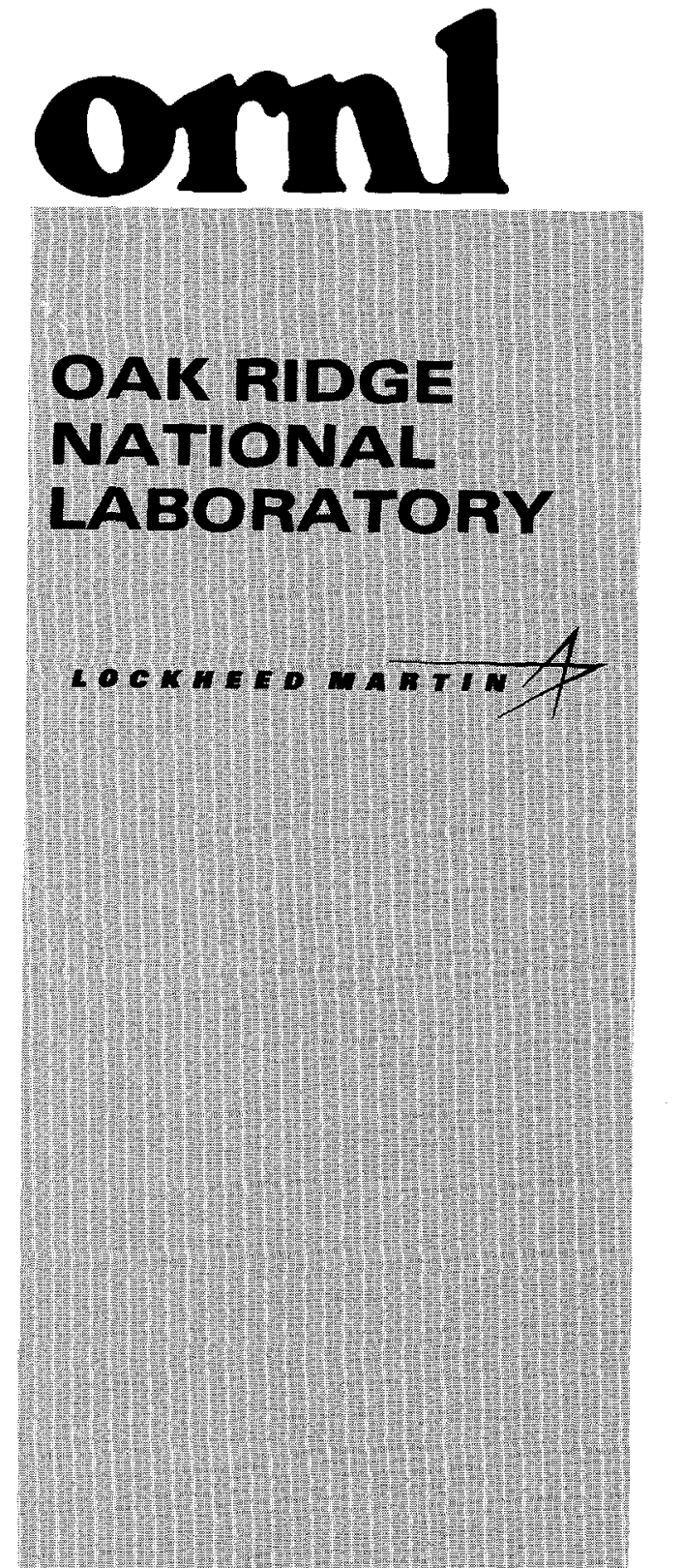

\section{}

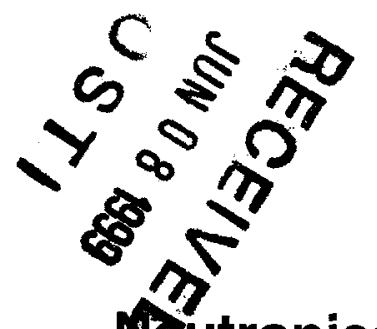

Autronics Benchmarks for the Utilization of Mixed-Oxide Fuel: Joint U.S./Russian Progress Report for Fiscal Year 1997

Volume 4, Part 7-Homogeneous Mixtures of Polystyrene-Moderated Plutonium and Uranium Oxides

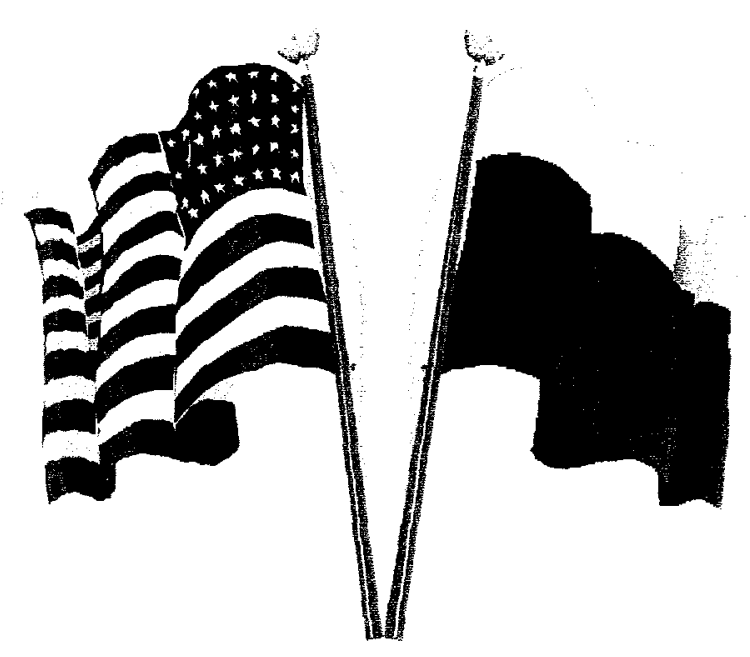

Fissile Materials Disposition Program 
This report was prepared as an account of work sponsored by an agency of the United States Government. Neither the United States Government nor any agency thereof, nor any of their employees, makes any warranty, express or implied, or assumes any legal liability or responsibility for the accuracy, completeness, or usefulness or any information, apparatus, product, or process disclosed, or represents that its use would not infringe privately owned rights. Reference herein to any specific commercial product, process, or service by trade name, trademark, manufacturer, or otherwise, does not necessarily constitute or imply its endorsement, recommendation, or favoring by the United States Govemment or any agency thereof. The views and opinions of authors expressed herein do not necessarily state or reflect those of the United States Government or any agency thereof. 


\section{DISCLAIMER}

Portions of this document may be illegible in electronic image products. Images are produced from the best available original document. 


\title{
NEUTRONICS BENCHMARKS FOR THE UTILIZATION OF MIXED-OXIDE FUEL: JOINT U.S./RUSSIAN PROGRESS REPORT FOR FISCAL YEAR 1997
}

\section{Volume 4, Part 7-Homogeneous Mixtures of Polystyrene-Moderated Plutonium and Uranium Oxides}

\author{
Musa Yavuz
}

Date Published: May 1999

\author{
Report Prepared by \\ LOCKHEED MARTIN ENERGY RESEARCH CORP. \\ P.O. Box 2008 \\ Oak Ridge, Tennessee 37831-6363 \\ Under \\ Subcontract Number 85B99398V \\ Funded by \\ Office of Fissile Materials Disposition \\ United States Department of Energy \\ Prepared for \\ Computational Physics and Engineering Division \\ Oak Ridge National Laboratory \\ Oak Ridge, Tennessee 37831 \\ managed by \\ LOCKHEED MARTIN ENERGY RESEARCH CORP. \\ for the \\ U.S. DEPARTMENT OF ENERGY \\ under contract DE-96OR22464
}




\title{
HOMOGENEOUS MIXTURES OF POLYSTYRENE-MODERATED PLUTONIUM AND URANIUM OXIDES
}

\author{
Evaluator \\ Musa Yavuz \\ Department of Mechanical Engineering \\ The University of Texas at Austin \\ Internal Reviewer \\ Naeem M. Abdurrahman \\ Department of Mechanical Engineering \\ The University of Texas at Austin
}

\section{External Reviewers}

M. E. Dunn

R. Trenton Primm III

Oak Ridge National Laboratory 


\section{HOMOGENEOUS MIXTURES OF POLYSTYRENE-MODERATED PLUTONIUM AND URANIUM OXIDES ${ }^{1}$}

\section{Detailed Description}

\subsection{Overview of Experiment}

In the 1970s at the Battelle Pacific Northwest Laboratory (PNL), a series of critical experiments using a remotely operated Split-Table Machine was performed with homogeneous mixtures of $(\mathrm{Pu}-\mathrm{U}) \mathrm{O}_{2}$ polystyrene fuels in the form of square compacts having different heights. With respect to Pu enrichments and moderation $\left[\mathrm{H} /(\mathrm{Pu}+\mathrm{U})\right.$ atomic] ratios $(\mathrm{MR})$, four-different homogeneous (Pu-U) $\mathrm{O}_{2}$-polystyrene mixtures were considered: Mixture 1) $7.6 \mathrm{wt} \% \mathrm{Pu}$ with $19.5 \mathrm{MR}$, Mixture 2) $7.89 \mathrm{wt} \% \mathrm{Pu}$ with $51.8 \mathrm{MR}$, Mixture 3) $14.62 \mathrm{wt}^{2} \mathrm{Pu}$ with $30.6 \mathrm{MR}$, and Mixture 4) $30.0 \mathrm{wt} \% \mathrm{Pu}$ with $47.4 \mathrm{MR}$. The $\mathrm{Pu}^{240}$ isotopic contents in $\mathrm{Pu}$ were $23 \mathrm{wt} \%$ for Mixture 1 and $8 \mathrm{wt} \%$ for Mixtures 2-4. In all mixtures, the uranium was depleted to about $0.151 \mathrm{wt}^{2} \mathrm{U}^{235}$. The critical geometric dimensions for both fully Plexiglas ${ }^{\mathrm{TM}}$ reflected $^{\mathrm{T}}$ and unreflected configurations were reported for Mixture 3 and 4 experiments. The dimensions for Mixture 1 and 2 experiments were given for fully-reflected assemblies.

This evaluation contains a total of 39 critical (fully reflected and bare) experimental configurations as well as 3 slab geometry critical dimensions.

\subsection{Description of Experimental Configuration}

A large glove box within a heavily shielded cell located at the PNL Critical Mass Laboratory (CML) was used for the experiments. The floor surface of CML was $1067 \mathrm{~cm}$ square, with $152-\mathrm{cm}$-thick side walls (except for a $91-\mathrm{cm}$-thick south wall) and a 61-cm-thick roof and floor [Smolen 1994]. A remotely operated Split-Table Machine (STM) shown in Fig. 1 was used for performing the experiments. Each half of the split table, one stationary and the other movable, had a steel frame. One of the table halves formed a surface of $76-\mathrm{cm}$ wide and $61-\mathrm{cm}$ long, and the other formed a surface of 76- $\mathrm{cm}$ wide and 46- $\mathrm{cm}$ long. The table surface was $51-\mathrm{cm}$ above the floor level.

A $30-\mathrm{cm}$ thick aluminum honeycomb material (effective Al density of $0.037 \mathrm{~g} / \mathrm{cm}^{3}$ ) covered both table halves [Richey 1965]. For Mixture 1 [Lloyd 1974], the geometric dimensions of compacts, including the uncertainties in the measurements for fuel, clad and stacking void are given in Table 1. For Mixtures 2-4 [Bierman 1973], the length and width of solid fuel compacts were in the range of $5.08-5.09 \mathrm{~cm}$, and the height having dimensions of $5.08,5.09,3.81$ and $1.27 \mathrm{~cm}$ was variable. Each of the fuel compacts was clad with a 6-mil-thick \#471 tape manufactured by Minnesota Mining and Manufacturing (3M) Company.

In Table 2, the experimentally corrected critical dimensions of the fuel assemblies are given for Mixture 1. For this mixture, Table 3 contains the number of compacts used in the experiments with the specified length, width, and height. The heights are given in number of compacts plus a compact of smaller size. Smaller size compacts should be treated as full layers of thinner fuel compacts having a thickness equal to the fractional layer "times" the thickness indicated for the compacts. The measured (corrected) critical

\footnotetext{
${ }^{1}$ Evaluator - Musa Yavuz, The University of Texas at Austin. Internal Reviewer - Naeem M. Abdurrahman, The University of Texas at Austin. External Reviewers - M. E. Dunn and R. Trenton Primm, III, Oak Ridge National Laboratory. Keywords: critical experiment, mixed oxide fuel, Plexiglas-reflected, plutonium, polystyrene-moderated, Split-Table Machine.
} 
dimensions and masses of fuel for Mixtures 2-4 experiments are given in Tables 4-6. In all experiments, the Plexiglas reflector had a thickness of $15 \mathrm{~cm}$.

Table 1. Fuel compact dimensions for Mixture 1

\begin{tabular}{cccc}
\hline Compacts & Length $(\mathrm{cm})$ & Width $(\mathrm{cm})$ & Height $(\mathrm{cm})$ \\
\hline Unclad & $5.090 \pm 0.005$ & $5.090 \pm 0.006$ & $5.088 \pm 0.018$ \\
& & & $1.279 \pm 0.040$ \\
Clad & $5.120 \pm 0.005$ & $5.120 \pm 0.005$ & $5.148 \pm 0.018$ \\
Stacked & & & $1.339 \pm 0.040$ \\
(clad + void) & $5.153 \pm 0.010$ & $5.153 \pm 0.010$ & $5.172 \pm 0.025$ \\
\hline
\end{tabular}

Table 2. Critical dimensions for Mixture 1 [843 $\mathrm{g}(\mathrm{Pu}+\mathrm{U}) / \mathrm{liter}]$

\begin{tabular}{cccc}
\hline & \multicolumn{3}{c}{ Critical dimensions (cm) } \\
\hline Case & Length & Width & Height $^{a}$ \\
\hline 1 & $61.08 \pm 0.06$ & $66.17 \pm 0.07$ & $30.49 \pm 0.15$ \\
2 & $61.08 \pm 0.06$ & $61.08 \pm 0.06$ & $31.80 \pm 0.16$ \\
3 & $66.17 \pm 0.07$ & $66.17 \pm 0.07$ & $29.24 \pm 0.16$ \\
4 & $61.08 \pm 0.06$ & $50.90 \pm 0.05$ & $35.61 \pm 0.18$ \\
5 & $61.08 \pm 0.06$ & $55.99 \pm 0.06$ & $33.24 \pm 0.16$ \\
6 & $50.90 \pm 0.05$ & $50.90 \pm 0.05$ & $40.76 \pm 0.20$ \\
$7^{b}$ & $47.27 \pm 0.20$ & $47.27 \pm 0.20$ & $47.27 \pm 0.20$ \\
\hline
\end{tabular}

${ }^{a}$ Experimentally determined corrections ( $12.7 \%$ reduction in critical height) accounting for the reactivity of the cladding material and the stacking voids.

${ }^{b}$ Cube dimensions obtained by interpolation between critical assemblies.

Table 3. Critical dimensions in terms of number of compacts for Mixture 1

\begin{tabular}{ccccc}
\hline & Fuel length & Fuel width & \multicolumn{2}{c}{ Fuel height } \\
Case & $5.09 \mathrm{~cm}$ & $5.09 \mathrm{~cm}$ & $5.088 \mathrm{~cm}$ & $1.279 \mathrm{~cm}^{a}$ \\
\hline 1 & 12 & 13 & 6 & $3.434 \pm 0.012$ \\
2 & 12 & 12 & 7 & $0.632 \pm 0.004$ \\
3 & 13 & 13 & 6 & $2.317 \pm 0.020$ \\
4 & 12 & 10 & 8 & $0.068 \pm 0.008$ \\
5 & 12 & 11 & 7 & $1.920 \pm 0.016$ \\
6 & 10 & 10 & 9 & $0.703 \pm 0.028$ \\
\hline
\end{tabular}

${ }^{a}$ Fractional layers should be treated as full layers having the fractional indicated thickness. 
Table 4. Critical dimensions and masses for Mixture $2[360 \mathrm{~g}(\mathrm{Pu}+\mathrm{U}) / \mathrm{liter}]$

\begin{tabular}{cccccc}
\hline & \multicolumn{3}{c}{ Critical dimensions (cm) } & \multicolumn{2}{c}{ Critical mass (kg) } \\
Case & Length & Width & Height $^{a}$ & $\mathrm{Pu}$ & $\mathrm{U}$ \\
\hline 1 & $40.72 \pm 0.04$ & $45.72 \pm 0.09$ & $32.89 \pm 0.12$ & $1.74 \pm 0.01$ & $20.29 \pm 0.22$ \\
2 & $50.90 \pm 0.05$ & $50.80 \pm 0.10$ & $26.40 \pm 0.10$ & $1.94 \pm 0.02$ & $22.63 \pm 0.25$ \\
3 & $61.08 \pm 0.06$ & $60.96 \pm 0.12$ & $22.66 \pm 0.08$ & $2.39 \pm 0.02$ & $27.88 \pm 0.31$ \\
4 & $61.08 \pm 0.06$ & $66.04 \pm 0.13$ & $22.09 \pm 0.18$ & $2.53 \pm 0.03$ & $29.53 \pm 0.39$ \\
5 & $61.08 \pm 0.06$ & $55.88 \pm 0.11$ & $23.22 \pm 0.08$ & $2.25 \pm 0.02$ & $26.26 \pm 0.28$ \\
6 & $61.08 \pm 0.06$ & $50.80 \pm 0.10$ & $24.37 \pm 0.09$ & $2.15 \pm 0.02$ & $25.06 \pm 0.28$ \\
7 & $40.72 \pm 0.05$ & $40.64 \pm 0.08$ & $36.42 \pm 0.13$ & $1.71 \pm 0.01$ & $19.97 \pm 0.22$ \\
$8^{b}$ & $39.12 \pm 0.28$ & $39.12 \pm 0.28$ & $39.12 \pm 0.28$ & $1.70 \pm 0.01$ & $19.84 \pm 0.32$ \\
$9^{c}$ & Infinite & Infinite & $14.83 \pm 0.60$ & - & -
\end{tabular}

${ }^{a}$ Experimentally determined corrections ( $15 \%$ reduction in critical height) accounting for the reactivity of the cladding material and the stacking voids.

${ }^{b}$ Cube dimensions obtained by interpolation between critical assemblies.

${ }^{c}$ Infinite slab thickness obtained by extrapolation of data.

Table 5. Critical dimensions and masses for Mixture $3[580 \mathrm{~g}(\mathrm{Pu}+\mathrm{U}) /$ liter]

\begin{tabular}{cccccc}
\hline \multicolumn{3}{c}{ Critical dimensions $(\mathrm{cm})$} & \multicolumn{3}{c}{ Critical mass (kg) } \\
Case & Length & Width & Height $^{a}$ & Pu & U \\
\hline 1 & $30.54 \pm 0.03$ & $40.72 \pm 0.04$ & $29.81 \pm 0.15$ & $3.14 \pm 0.04$ & $18.35 \pm 0.35$ \\
2 & $40.72 \pm 0.04$ & $40.72 \pm 0.04$ & $23.84 \pm 0.10$ & $3.35 \pm 0.04$ & $19.57 \pm 0.37$ \\
3 & $45.81 \pm 0.04$ & $50.90 \pm 0.05$ & $19.82 \pm 0.11$ & $3.92 \pm 0.05$ & $22.89 \pm 0.44$ \\
4 & $50.90 \pm 0.04$ & $50.90 \pm 0.05$ & $18.92 \pm 0.09$ & $4.16 \pm 0.05$ & $24.28 \pm 0.46$ \\
5 & $61.08 \pm 0.06$ & $50.90 \pm 0.05$ & $17.72 \pm 0.09$ & $4.67 \pm 0.06$ & $27.28 \pm 0.52$ \\
6 & $61.08 \pm 0.06$ & $61.08 \pm 0.06$ & $16.53 \pm 0.09$ & $5.26 \pm 0.06$ & $30.73 \pm 0.59$ \\
$7^{b}$ & $33.30 \pm 0.17$ & $33.30 \pm 0.17$ & $33.30 \pm 0.17$ & $3.13 \pm 0.05$ & $18.28 \pm 0.40$ \\
$8^{c}$ & Infinite & Infinite & $11.56 \pm 0.09$ & - & - \\
$9^{d}$ & $40.72 \pm 0.04$ & $40.76 \pm 0.17$ & $52.39 \pm 0.07$ & $7.37 \pm 0.05$ & $43.06 \pm 0.82$ \\
$10^{d}$ & $40.72 \pm 0.04$ & $45.86 \pm 0.19$ & $45.10 \pm 0.06$ & $7.14 \pm 0.08$ & $41.70 \pm 0.79$ \\
$11^{d}$ & $50.90 \pm 0.05$ & $45.86 \pm 0.19$ & $36.99 \pm 0.05$ & $7.32 \pm 0.08$ & $42.75 \pm 0.81$ \\
$12^{d}$ & $43.78 \pm 0.07$ & $43.78 \pm 0.07$ & $43.78 \pm 0.07$ & $7.12 \pm 0.08$ & $41.55 \pm 0.80$ \\
\hline${ }^{a}$ Experimentally determined corrections $(\sim 4 \%$ reduction in critical height) accounting for the reactivity of \\
the cladding material and the stacking voids. \\
bube dimensions obtained by interpolation between critical assemblies. \\
${ }^{b}$ Infinite slab thickness obtained by extrapolation of data. \\
${ }^{d}$ Bare (unreflected) critical dimensions.
\end{tabular}


Table 6. Critical dimensions and masses for Mixture 4 [373 $\mathrm{g}(\mathrm{Pu}+\mathrm{U}) / \mathrm{liter}]$

\begin{tabular}{cccccc}
\hline & \multicolumn{2}{c}{ Critical dimensions (cm) } & \multicolumn{2}{c}{ Critical mass (kg) } \\
Case & Length & Width & Height $^{a}$ & $\mathrm{Pu}$ & $\mathrm{U}$ \\
\hline 1 & $30.54 \pm 0.03$ & $30.54 \pm 0.03$ & $30.89 \pm 0.02$ & $3.23 \pm 0.05$ & $7.53 \pm 0.12$ \\
2 & $35.63 \pm 0.04$ & $35.63 \pm 0.04$ & $23.95 \pm 0.10$ & $3.40 \pm 0.05$ & $7.94 \pm 012$ \\
3 & $40.72 \pm 0.04$ & $40.72 \pm 0.04$ & $20.22 \pm 0.05$ & $3.75 \pm 0.05$ & $8.76 \pm 0.13$ \\
4 & $50.90 \pm 0.05$ & $45.81 \pm 0.05$ & $17.14 \pm 0.07$ & $4.48 \pm 0.06$ & $10.44 \pm 0.16$ \\
5 & $61.08 \pm 0.06$ & $50.90 \pm 0.05$ & $15.53 \pm 0.11$ & $5.44 \pm 0.08$ & $12.69 \pm 0.20$ \\
6 & $61.08 \pm 0.06$ & $55.99 \pm 0.06$ & $15.16 \pm 0.02$ & $5.80 \pm 0.09$ & $13.51 \pm 0.21$ \\
7 & $66.17 \pm 0.06$ & $61.08 \pm 0.06$ & $14.43 \pm 0.10$ & $6.53 \pm 009$ & $15.24 \pm 0.22$ \\
8 & $50.90 \pm 0.02$ & $50.90 \pm 0.05$ & $16.49 \pm 0.04$ & $4.78 \pm 0.08$ & $11.14 \pm 0.18$ \\
$9^{b}$ & $30.60 \pm 0.02$ & $30.60 \pm 0.02$ & $30.60 \pm 0.02$ & $3.21 \pm 0.05$ & $7.49 \pm 0.12$ \\
$10^{c}$ & Infinite & Infinite & $10.80 \pm 0.11$ & - & - \\
$11^{d}$ & $45.81 \pm 0.05$ & $40.72 \pm 0.04$ & $37.98 \pm 0.06$ & $7.93 \pm 0.12$ & $18.51 \pm 0.78$ \\
$12^{d}$ & $40.72 \pm 0.04$ & $40.72 \pm 0.04$ & $42.24 \pm 0.03$ & $7.84 \pm 0.11$ & $18.30 \pm 0.77$ \\
$13^{d}$ & $45.81 \pm 005$ & $50.90 \pm 0.05$ & $32.49 \pm 0.02$ & $7.84 \pm 0.12$ & $19.80 \pm 0.84$ \\
$14^{d}$ & $41.20 \pm 0.05$ & $41.20 \pm 0.05$ & $41.20 \pm 0.05$ & $7.83 \pm 0.11$ & $18.28 \pm 0.77$ \\
\hline
\end{tabular}

${ }^{a}$ Experimentally determined corrections ( $2 \%$ reduction in critical height) accounting for the reactivity of the cladding material and the stacking voids.

${ }^{b}$ Cube dimensions obtained by interpolation between critical assemblies.

${ }^{c}$ Infinite slab thickness obtained by extrapolation of data.

${ }^{d}$ Bare (unreflected) critical dimensions.

\subsection{Description of Material Data}

The number densities of nuclides contained in fuel (MOX+polystyrene), clad (\#471 3M tape) and reflector (methacrylate plastic or Plexiglas) are given in Table 7 for Mixtures $1-4$. The ${ }^{239} \mathrm{Pu}$ content in Pu was $68 \%$ for Mixture 1, and 91\% for Mixtures 2-4.

Table 7. Composition of fuel, clad and reflector

\begin{tabular}{|c|c|c|c|c|c|c|}
\hline \multirow[b]{2}{*}{ Nuclide } & \multicolumn{6}{|c|}{ Atomic density $\left(\mathrm{E}+24 \text { atom } / \mathrm{cm}^{3}\right)^{a}$} \\
\hline & $\begin{array}{c}\text { Mixture } 1 \\
{[843 \mathrm{~g}} \\
(\mathrm{Pu}+\mathrm{U}) / \text { liter }]\end{array}$ & $\begin{array}{c}\text { Mixture } 2 \\
(408 \mathrm{~g} \\
\text { Oxide/liter) }\end{array}$ & $\begin{array}{c}\text { Mixture } 3 \\
\text { (660 g } \\
\text { Oxide/liter) }\end{array}$ & $\begin{array}{c}\text { Mixture } 4 \\
(426 \mathrm{~g} \\
\text { Oxide/liter) }\end{array}$ & $\begin{array}{c}\text { Clad } \\
\text { (3M tape) }\end{array}$ & $\begin{array}{l}\text { Reflector } \\
\text { (plexiglas) }\end{array}$ \\
\hline $\mathrm{Am}^{241}$ & $3.766 \mathrm{E}-07$ & $1.741 \mathrm{E}-07$ & $4.036 \mathrm{E}-07$ & $3.511 \mathrm{E}-07$ & & \\
\hline $\mathrm{Pu}^{238}$ & $9.535 \mathrm{E}-07$ & 0.0 & 0.0 & 0.0 & & \\
\hline $\mathrm{Pu}^{239}$ & $1.092 \mathrm{E}-04$ & $6.528 \mathrm{E}-05$ & $1.954 \mathrm{E}-04$ & $2.578 \mathrm{E}-04$ & & \\
\hline $\mathrm{Pu}^{240}$ & $3.688 \mathrm{E}-05$ & $5.941 \mathrm{E}-06$ & $1.702 \mathrm{E}-05$ & $2.257 \mathrm{E}-05$ & & \\
\hline $\mathrm{Pu}^{241}$ & $8.945 \mathrm{E}-06$ & $3.481 \mathrm{E}-07$ & $1.211 \mathrm{E}-06$ & $1.756 \mathrm{E}-06$ & & \\
\hline $\mathrm{Pu}^{242}$ & $4.689 \mathrm{E}-06$ & 0.0 & 0.0 & 0.0 & & \\
\hline $\mathrm{U}^{235}$ & $2.897 \mathrm{E}-06$ & $1.285 \mathrm{E}-06$ & $1.904 \mathrm{E}-06$ & $1.008 \mathrm{E}-06$ & & \\
\hline $\mathrm{U}^{238}$ & $1.968 \mathrm{E}-03$ & $8.376 \mathrm{E}-04$ & $1.252 \mathrm{E}-03$ & $6.604 \mathrm{E}-04$ & & \\
\hline $\mathrm{O}$ & $4.348 \mathrm{E}-03$ & $1.830 \mathrm{E}-03$ & $3.023 \mathrm{E}-03$ & $1.974 \mathrm{E}-03$ & & $1.428 \mathrm{E}-02$ \\
\hline $\mathrm{H}$ & $4.155 \mathrm{E}-02$ & 4.719E-02 & $4.489 \mathrm{E}-02$ & $4.468 \mathrm{E}-02$ & $4.489 \mathrm{E}-02$ & $5.712 \mathrm{E}-02$ \\
\hline $\mathrm{C}$ & $4.287 \mathrm{E}-02$ & $4.540 \mathrm{E}-02$ & $4.412 \mathrm{E}-02$ & $4.537 \mathrm{E}-02$ & $3.110 \mathrm{E}-02$ & $3.570 \mathrm{E}-02$ \\
\hline $\mathrm{Cl}$ & - & - & - & - & $7.24 \mathrm{E}-03$ & - \\
\hline
\end{tabular}

${ }^{a}$ Read E+24 as $10^{24}$. 
In Table 7, the number density for $\mathrm{U}^{235}$ of Mixture 4 is an order of magnitude lower than what was given in [Bierman 1973]. The reason for this is explained in Section 2 (Evaluation of Experimental Data). For Mixture 1, the cladding material per compact was $3.175 \mathrm{~g}$ and the cladding density was $1.12 \mathrm{~g} / \mathrm{cm}^{3}$. Uranium density per compact was $0.779 \pm 0.006 \mathrm{~g} / \mathrm{cm}^{3}$, the plutonium density was $0.064 \pm 0.001 \mathrm{~g} / \mathrm{cm}^{3}$ and the total fuel density was $1.884 \pm 0.015 \mathrm{~g} / \mathrm{cm}^{3}$. For Mixtures $2-4$, the cladding properties were not given because of the reported critical dimensions that account for the reactivity effect of the cladding and stacking void. The measured critical masses of plutonium and uranium are given in Tables 4-6. Particle size distributions which indicate the homogeneity are presented in Table 8 for Mixtures 1-4.

Table 8. Particle size distributions

\begin{tabular}{ccccc}
\hline & \multicolumn{5}{c}{ Particle diameter $(\mu \mathrm{m})$} \\
$\begin{array}{c}\text { Distribution } \\
(\%)\end{array}$ & $\begin{array}{c}\text { Mixture 1 } \\
\mathrm{PuO}_{2}-\mathrm{UO}_{2}\end{array}$ & \multicolumn{2}{c}{ Mixtures 2-4 } \\
\hline 95 & - & $<20$ & $<\mathrm{UuO}_{2}$ & Polystyrene \\
\hline 90 & $<20$ & - & - & $<225$ \\
50 & $<5$ & $<5$ & $<9$ & - \\
10 & $<0.8$ & - & - & -150 \\
5 & - & $<0.5$ & $<3$ & $<50$ \\
\hline
\end{tabular}

\subsection{Supplemental Experimental Measurements}

Inverse multiplication measurements to determine the critical dimensions were performed for both unreflected and fully Plexiglas-reflected configurations for Mixtures 3 and 4. Measurements for Mixtures 1 and 2 were only considered for fully reflected assemblies because of the large volume requirement for unreflected assemblies.

For Mixtures 2-4, critical dimensions in length, width, and experimentally corrected heights were reported. Also, experimentally corrected critical masses of solid fuel assemblies were presented. The corrections on the critical dimensions and masses were made to account for the reactivity effect of cladding and the presence of voids in the assembly of stacked compacts. These corrections were obtained by observing the change in critical mass due to varying the number of layers of cladding on the fuel compacts. For Mixture 1, the experimental assemblies were provided both in terms of fuel compacts and corrected critical dimensions of fuel only. For bare assemblies, an additional correction was also made to account for the reactivity effect of the structural material. The correction was an increase of $0.05 \%$ in the critical mass of each bare assembly.

Buckling measurements were performed for six bare critical assemblies. The extrapolation distances of $2.56 \mathrm{~cm}$ for Mixture 4 and $2.49 \mathrm{~cm}$ for Mixture 3 were calculated. The critical buckling values together with critical dimensions are shown in Table 9 for Mixtures 3 and 4. 
Table 9. Critical buckling for Mixtures 3 and 4

\begin{tabular}{|c|c|c|c|}
\hline \multicolumn{4}{|c|}{ Mixture 4 [373 g/(Pu+U)/liter] } \\
\hline \multicolumn{3}{|c|}{ Critical dimensions $(\mathrm{cm}), \lambda=2.56 \pm 0.08 \mathrm{~cm}^{*}$} & \multirow{2}{*}{$B_{g}^{2}\left(\mathrm{~m}^{-2}\right)$} \\
\hline Width & Length & Height & \\
\hline $45.81 \pm 0.05$ & $40.72 \pm 0.04$ & $37.98 \pm 0.06$ & $138.16 \pm 1.34$ \\
\hline $40.72 \pm 0.04$ & $40.72 \pm 0.04$ & $42.24 \pm 0.03$ & $137.94 \pm 1.28$ \\
\hline \multirow[t]{2}{*}{$45.81 \pm 0.05$} & $50.90 \pm 0.04$ & $32.49 \pm 0.03$ & $139.27 \pm 1.54$ \\
\hline & Average & & $138.46 \pm 1.39$ \\
\hline \multicolumn{4}{|c|}{ Mixture $3[580 \mathrm{~g} /(\mathrm{Pu}+\mathrm{U}) /$ liter $]$} \\
\hline \multicolumn{3}{|c|}{ Critical dimensions $(\mathrm{cm}), \lambda=2.49 \pm 0.07 \mathrm{~cm}^{*}$} & \multirow{2}{*}{$B_{g}^{2}\left(\mathrm{~m}^{-2}\right)$} \\
\hline Width & Length & Height & \\
\hline $40.76 \pm 0.17$ & $40.72 \pm 0.04$ & $52.39 \pm 0.07$ & $124.42 \pm 1.47$ \\
\hline $45.86 \pm 0.19$ & $40.72 \pm 0.04$ & $45.10 \pm 0.06$ & $124.79 \pm 1.36$ \\
\hline \multirow[t]{2}{*}{$45.86 \pm 0.19$} & $50.90 \pm 0.05$ & $36.99 \pm 0.05$ & $125.82 \pm 1.43$ \\
\hline & Average & & $125.01 \pm 1.43$ \\
\hline
\end{tabular}

*Extrapolation length.

\section{Evaluation of Experimental Data}

Material densities for fuel compacts (Mixtures 1-4) were documented in detail. However, the MR for Mixture 4 is not 47.4. Also, the $U^{235}$ enrichment in $U$ does not correspond to the reported $0.151 \mathrm{wt} \%$. The number density for $\mathrm{U}^{235}$ given in [Bierman 1973] is an order of magnitude high. The corrected number density of $1.008 \leftrightarrow 10^{-6}$ is used in Table 7 , rather than $1.008 \leftrightarrow 10^{-5}$. With this correction, the MR becomes 47.35 which is in agreement with the reported 47.4. Also, the enrichment of $U^{235}$ becomes about 0.151 wt $\%$. The rest of the material densities were correctly presented.

The geometric units of compacts were given in inches in [Bierman 1973], but the SI units were used in presenting the critical dimensions. In this evaluation, we use the SI units to be consistent with the critical dimensions.

Although the geometric (fuel-clad-void) compact data for Mixture 1 is well presented, this is not the case for Mixtures 2-4. Cladding compositions for Mixtures 2-4 compacts were not given although it is defined by \#471 3M tape. The \#471 3M tape composition [Bierman 1996] is the same as the Mixture 1 compacts. The stacking void per compact was not provided for these mixture experiments. Instead, the critical sizes and masses were given for solid assemblies of fuel only. Experimentally determined corrections were applied in each case to account for the reactivity effect of the cladding material and the presence of voids in the assembly of the stacked blocks.

The experimentally corrected dimensions of solid fuels were determined graphically. In these graphs, the critical height was plotted as a function of layers of cladding material. Using the data points in these plots, the critical height was extrapolated to zero cladding to determine the critical height of solid fuels only. These plots indicate that for Mixture 4 experiments, there were 3 data points $(1,2$, and 3 layers of clad). However, for Mixtures 1-3, there were 2 data points in the reported figures ( 1 and 2 layers of clad). The fitted curve for Mixture 4 appears to be linear.

For bare assemblies, it is reported that there was only $0.05 \%$ increase in critical masses due to structural supports, but the descriptions of these were not given. Also, the exact location of the split table machine (STM) in the heavily shielded cell was not described. In addition, the critical dimensions were determined for slab by extrapolation of data and cube by interpolation between critical assemblies. 
The critical dimensions reported in [Bierman 1973] for $(\mathrm{Pu}-\mathrm{U}) \mathrm{O}_{2}$-polystyrene and $\left(\mathrm{Pu}^{239}-\mathrm{U}\right) \mathrm{O}_{2}$-water mixtures in spherical, cylindrical, and slab geometries are not included in this evaluation. These dimensions were calculated by extrapolating one, two or three experimental data points.

For Mixtures 2-4, the experimentally corrected dimensions of solid fuels were given. However, for Mixture 1, the critical dimensions were provided both in terms of number of compacts and the experimentally corrected dimensions of solid assemblies of fuel only. Thus, for Mixture 1:

(a) the corrected dimensions in Table 2 can be calculated from those in Table 3 , and

(b) if the $\mathrm{k}_{\text {eff }}$ of the experiments both in terms of number of compacts and the experimentally corrected dimensions are within the statistical uncertainty, then the corrected dimensions can directly be used for simplifying the computational modeling.

To check " $a$ ", the corrected dimensions in Table 2 are calculated using Table 3 dimensions. (The length and the width dimensions of compacts agree each other as seen in Tables 2 and 3.) The corrected critical height given in Table 2 is a $12.7 \%$ reduction (accounting for the reactivity effect of the clad and the stacking voids) of the critical height given in Table 3. To verify this, for example, the total fuel height of Case 1 in Table 3 is $6 \leftrightarrow 5.088+3 \leftrightarrow 1.279+(5.12 / 5.088)^{2} \leftrightarrow 1.279 \leftrightarrow 0.434=34.927 \mathrm{~cm}$. Considering a $12.7 \%$ experimental reduction, the critical height is $(1.0-0.127) \leftrightarrow 34.927=30.491 \mathrm{~cm}$, which agrees with the Case 1 dimension of $30.49 \mathrm{~cm}$ given in Table 2. Also, all the other dimensions in Tables 2 and 3 agree each other in this manner.

To verify " $b$ ", MCNP calculations were performed. Polyethylene (poly.01t) thermal cross sections both in Fuel and Plexiglas was used. The calculated $k_{\text {eff }}$ are $0.98210 \pm 0.00154$ for the Case 1 of Table 2 and $0.98264 \pm 0.00094$ for the Case 1 of Table 3. Also, the calculated $k_{\text {eff }}$ are $0.98635 \pm 0.00125$ for the Case 2 of Table 2, and $0.98634 \pm 0.00139$ for the Case 2 of Table 3. Thus, $k_{\text {effs }}$ agree each other within the statistical uncertainty. This suggests that the experimentally corrected critical dimensions can directly be used in modeling the experiments. The input listings for these cases are given in Section 6. (Sample MCNP Input Listings.)

\section{Benchmark Specifications}

\subsection{Description of Model}

In the benchmark models, experimentally corrected solid fuel critical dimensions accounting for the reactivity effect of the cladding and the stacking voids are considered in calculating $\mathrm{k}_{\text {effs. }}$. Plexiglas surrounding the assemblies is used as reflector.

\subsection{Dimensions}

The corrected critical dimensions given in Tables 2, 4, 5, and 6 are used for Mixtures 1-4 experiments, respectively. In all assemblies, a $15-\mathrm{cm}$-thick Plexiglas reflector is used.

\subsection{Material Data}

The number densities of Mixtures 1-4 are given in Table 7 .

\subsection{Temperature Data}

Because temperature data was not reported, a room temperature of $300 \mathrm{~K}$ is assumed. 


\section{Results of Sample Calculations}

The sample $k_{\text {eff }}$ calculations were performed using the MCNP4A continuous cross section library based on the ENDF/B-VI data. Polyethylene thermal cross sections (poly.01t card) are used for both fuel mixtures and Plexiglas. In the calculations, 4000 particle histories, 100 active and 25 skipped generations were used. However, additional particle histories were made if $k_{\text {eff }}$ had not attained a constant level after 400000 active particle histories. In Table 10, the calculated $k_{\text {eff }}$ are listed for the critical dimensions given in Tables 2 , and 4-6 for Mixtures 1-4, respectively.

Table 10. MCNP $k_{\text {eff }}$ for cases in Tables $2,4,5$, and 6

\begin{tabular}{ccccc}
\hline Case & Table 2 & Table 4 & Table 5 & Table 6 \\
\hline 1 & $0.98210 \pm 0.00154$ & $1.02956 \pm 0.00140$ & $1.01503 \pm 0.00155$ & $1.00690 \pm 0.00155$ \\
2 & $0.98635 \pm 0.00125$ & $1.02315 \pm 0.00136$ & $1.01885 \pm 0.00133$ & $1.00819 \pm 0.00134$ \\
3 & $0.98532 \pm 0.00123$ & $1.02144 \pm 0.00124$ & $1.01331 \pm 0.00135$ & $1.00699 \pm 0.00145$ \\
4 & $0.98645 \pm 0.00142$ & $1.02099 \pm 0.00212$ & $1.01105 \pm 0.00139$ & $1.00310 \pm 0.00148$ \\
5 & $0.98858 \pm 0.00134$ & $1.01867 \pm 0.00122$ & $1.01567 \pm 0.00159$ & $1.00470 \pm 0.00148$ \\
6 & $0.99110 \pm 0.00130$ & $1.02351 \pm 0.00137$ & $1.01549 \pm 0.00138$ & $1.00243 \pm 0.00154$ \\
7 & $0.99372 \pm 0.00062$ & $1.02940 \pm 0.00125$ & $1.02286 \pm 0.00143$ & $1.00846 \pm 0.00131$ \\
8 & & $1.02813 \pm 0.00130$ & $1.00208 \pm 0.00126$ & $1.00565 \pm 0.00141$ \\
9 & & $0.99725 \pm 0.00116$ & $1.01234 \pm 0.00151$ & $1.00539 \pm 0.00137$ \\
10 & & & $1.01033 \pm 0.00158$ & $1.01431 \pm 0.00122$ \\
11 & & & $1.00995 \pm 0.00151$ & $0.99572 \pm 0.00177$ \\
12 & & & $1.01396 \pm 0.00159$ & $0.99302 \pm 0.00183$ \\
13 & & & & $0.99148 \pm 0.00152$ \\
14 & & & & $0.99545 \pm 0.00155$ \\
\hline
\end{tabular}

\section{References}

Bierman 1973. S. R. Bierman. E. D. Clayton, and L. E. Hansen, "Critical Experiments with Homogeneous Mixtures of Plutonium and Uranium Oxides Containing 8, 15, and $30 \mathrm{wt} \%$ Plutonium," Nucl. Sci. Eng., 50, 115-126 (1973).

Lloyd 1974. R. C. Lloyd, S. R. Bierman, and E. D. Clayton, "Criticality of Plutonium-Uranium Mixtures Containing 5-8 wt\% Plutonium," Nucl. Sci. Eng., 55, 51-57 (1974).

Richey 1965. C. R. Richey, J. D. White, E. D. Clayton, and R. C. Lloyd, "Criticality of Homogeneous Plutonium Oxide-Plastic Compacts at H:Pu = 15," Nucl. Sci. Eng., 23, 150-158 (1965).

Smolen 1994. G. R. Smolen, R. C. Lloyd, and H. Funabashi, "Critical Data and Validation Studies of Plutonium-Uranium Nitrate Solutions in Cylindrical and Slab Geometry," Nuclear Technology, 107, 304 (1994).

Bierman 1996. S. R. Bierman, private communication, December 1996. 


\subsubsection{Sample MCNP Input Listings}

CASE 1 of TABLE 2: 7.6 wt $\%$ Pu; $\mathrm{H}:(\mathrm{U}+\mathrm{Pu})=19.5$ Moderation Ratio

C Cell Cards -Full Layer Compacts

$1 \quad 10.0908999411 \quad 1-2 \quad 3-4 \quad 5-6$ imp:n=1 \$ Fuel

$\begin{array}{lllllllll}2 & 2 & 0.1071 & 7 & -8 & 9 & -10 & 11 & -12\end{array}$

\#1 imp:n=1 \$ Plexiglas

$3 \quad 0 \quad-7: 8:-9: 10:-11: 12$ imp:n=0 $\$$ outside of the assembly

C Surface Cards

C Full Size Fuel Compact Dimensions

$1 \quad \mathrm{pz}-15.245$

2 pz 15.245 \$ Fuel Height

$3 \quad \mathrm{px}-30.54$

4 px 30.54 \$ Fuel Length

$5 \quad$ py -33.085

6 py $33.085 \$$ Fuel width

C Plexiglas Reflector (15 cm-thick)

$7 \quad \mathrm{pz}-30.245$

$8 \quad \mathrm{pz} \quad 30.245$

$9 \quad \mathrm{px}-45.54$

10 px 45.54

11 py -48.095

12 py 48.095

kcode 4000125125

ksrc 0.0 .0 .

print

m1 $95241.60 \mathrm{c} \quad 3.766 e-7 \quad 94238.60 \mathrm{c} \quad 9.535 e-7 \quad 94239.60 \mathrm{c} \quad 1.092 \mathrm{e}-4$

$94240.60 c \quad 3.688 e-594241.60 c \quad 8.945 e-6 \quad 94242.60 c \quad 4.689 e-6$

$92235.60 \mathrm{c} 2.897 e-6 \quad 92238.60 \mathrm{c} 1.968 e-3 \quad 8016.60 \mathrm{c} \quad 4.348 e-3$

$1001.60 \mathrm{c} 4.155 \mathrm{e}-2 \quad 6000.60 \mathrm{c} 4.287 \mathrm{e}-2$ \$ Fuel Composition

$\mathrm{m} 2 \quad 1001.60 \mathrm{c} \quad 5.712 \mathrm{e}-2 \quad 6000.60 \mathrm{c} \quad 3.570 \mathrm{e}-2 \quad 8016.60 \mathrm{c} \quad 1.428 \mathrm{e}-2$

Composition

$\$$ Plexiglas Reflector

m1t poly.01t

m2t poly.01t 
CASE 1 of Table 3: 7.6 wt\% Pu; $\mathrm{H}:(\mathrm{U}+\mathrm{Pu})=19.5$ Moderation Ratio

C Cell Cards -Full Compacts (5.09 x 5.09 x 5.088)

$11 \quad 1 \quad 0.0908999411 \quad 1-2 \quad 3-4 \quad 5-6 \quad u=1 \quad i m p: n=1$

$\$(\mathrm{Pu}+\mathrm{U}) \mathrm{O}_{-2}$-Polystyrene Mixture

$\begin{array}{lllllllll}2 & 2 & 0.08323 & 7 & -8 & 9 & -10 & 11 & -12\end{array}$

\#1 $\mathrm{u}=1$ imp:n=1 \$ 3M-clad

30 \# \#2 $0=1$ imp:n=1 \$ stacking Void

C $12 \times 13 \times 6$ Fuel Blocks

$4 \quad 0 \quad 13-14 \quad 15-16 \quad 17-18$ imp:n=1 lat=1 $u=2$

$\mathrm{fill}=-5: 0-11: 0-12: 0 \quad 1935 \mathrm{R} \quad \$ 12 \times 13 \times 6$ Fuel Blocks

$5 \quad 0 \quad 19-20 \quad 21-22 \quad 23-24$ fill=2 imp:n=1

C -Smaller Compacts (5.09 x $5.09 \times 1.279)$

$6 \quad \begin{array}{lllllllll}6 & 0.0908999411 & 27 & -28 & 3 & -4 & 5 & -6 & u=3\end{array}$ imp: $n=1$

7 $\$(\mathrm{Pu}+\mathrm{U}) \mathrm{O}_{2}$ 2-Polystyrene Mixture

$\begin{array}{lllllllll}7 & 2 & 0.08323 & 26 & -29 & 9 & -10 & 11 & -12\end{array}$

\#6 $u=3$ imp:n=1 \$ 3M-clad

$80 \quad \# 6 \# 7 \quad u=3$ imp:n=1 \$ stacking Void

C $12 \times 13 \times 3$ Fuel Blocks

$9 \quad 0 \quad 20-30 \quad 15-16 \quad 17-18$ imp:n=1 lat=1 $u=4$

fil1=-2:0 - $11: 0-12: 0 \quad 3467 \mathrm{R} \quad \$ 12 \times 13 \times 3$ Fuel Blocks

$10 \quad 0 \quad 31-32 \quad 21 \quad-22 \quad 23 \quad-24$ fil1=4 imp:n=1

C Fractional Layer

$11 \quad \begin{array}{lllllllll}1 & 0.0908999411 & 32 & -34 & 15 & -22 & 17 & -24 & \text { imp: } n=1\end{array}$

12 3 $0.1071 \# 5$ ( $\quad$ ( $10+\mathrm{U}) 02$-Polystyrene Mixture

$\begin{array}{lll}1 & 42 & -43\end{array}$

imp:n=1 \$Plexiglas Reflector

$130-38: 39:-40: 41:-42: 43$ imp:n=0 $\$$ Outside of Critical Assembly

C Surface Cards

C Full Size Fuel Compacts

$2 \quad \mathrm{pz} 5.13 \quad$ \$ Fuel Height

$3 \quad \mathrm{px} \quad 0.0315$

4 px 5.1215 \$ Fuel Length

5 py 0.0315

6 py 5.1215 \$ Fuel width

C Clad Compacts

7 pz 0.012

$8 \quad \mathrm{pz} \quad 5.16$

$9 \quad \mathrm{px} 0.0165$

$10 \mathrm{px} 5.1365$

11 py 0.0165

12 py 5.1365

C stacked Compacts (Fuel+Clad+Void)

13 pz 0.0

14 pz 5.172

15 px 0.0

16 px 5.153

17 py 0.0

18 py 5.153

C Window surfaces

19 pz 0.000001

20 pz 31.031999

21 px 0.000001

22 px 61.835999

23 py 0.000001

24 py 66.988999 
$\mathrm{C}$

C Smaller Fuel Compact having height of $1.279 \mathrm{~cm}$

C

26 pz 31.0735

27 pz 31.1035

$28 \quad \mathrm{pz} 32.3825$

29 pz 32.4125

30 pz 32.454

C Window Surfaces

$31 \mathrm{pz} \quad 31.032$

32 pz 35.297999

C Fractional layer on top

$34 \quad$ pz 35.853086

C Reflector

$38 \mathrm{pz}-15$.

39 pz 50.853086

40 px -15 .

41 px 76.836

42 py -15 .

43 py 81.989

kcode 4000125225

ksrc 31.33 .518 .

c print

m1 $95241.60 \mathrm{c} \quad 3.766 \mathrm{e}-7 \quad 94238.60 \mathrm{c} \quad 9.535 \mathrm{e}-7 \quad 94239.60 \mathrm{c} \quad 1.092 \mathrm{e}-4$

$94240.60 \mathrm{C} \quad 3.688 \mathrm{e}-5 \quad 94241.60 \mathrm{c} \quad 8.945 e-6 \quad 94242.60 \mathrm{c} \quad 4.689 e-6$

$92235.60 \mathrm{c} 2.897 e-6 \quad 92238.60 \mathrm{c} 1.968 \mathrm{e}-3 \quad 8016.60 \mathrm{c} 4.348 \mathrm{e}-3$

$1001.60 c 4.155 e-2 \quad 6000.60 c \quad 4.287 e-2 \quad \$$ Fuel composition

m2 $1001.60 \mathrm{c} 4.489 \mathrm{e}-2 \quad 6000.60 \mathrm{c} 3.110 \mathrm{e}-2 \quad 17000.60 \mathrm{c} \quad 7.240 \mathrm{e}-3$ $\$$ Clad Composition

m3 $1001.60 \mathrm{c} 5.712 \mathrm{e}-2 \quad 6000.60 \mathrm{c} 3.570 \mathrm{e}-2 \quad 8016.60 \mathrm{c} 1.428 \mathrm{e}-2$ $\$$ Plexiglas Reflector Composition

mit poly.01t

m2t poly.01t

m3t poly.01t 
CASE 2 of TABLE 2: 7.6 wt: Pu; $\mathrm{H}:(\mathrm{U}+\mathrm{Pu})=19.5$ Moderation Ratio

C Cell Cards -Full Layer Compacts

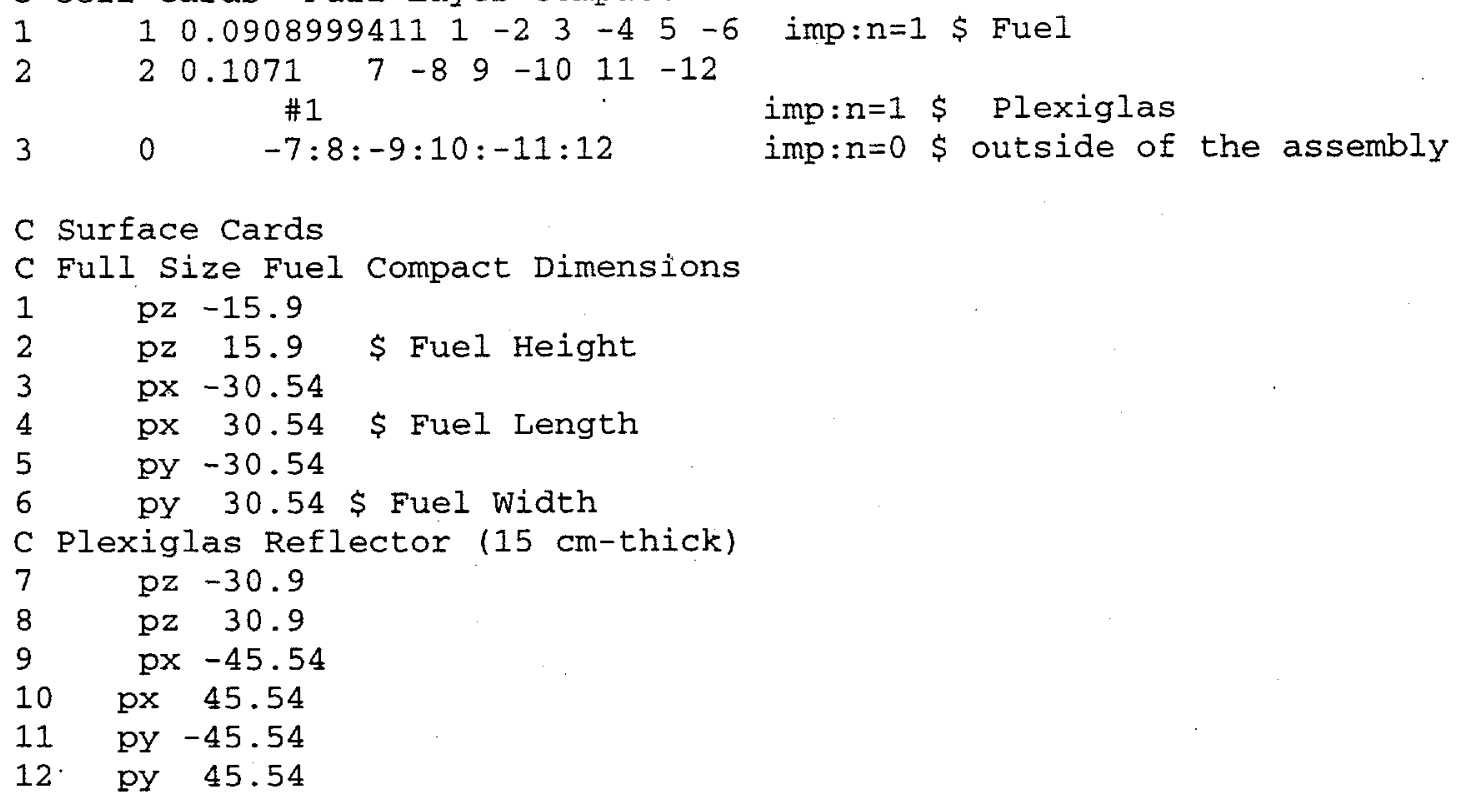

kcode 4000125125

ksrc 0.0 . 0 .

print

m1 $95241.60 \mathrm{c} \quad 3.766 e-7 \quad 94238.60 \mathrm{c} \quad 9.535 e-7 \quad 94239.60 \mathrm{c} \quad 1.092 \mathrm{e}-4$

$94240.60 \mathrm{c} 3.688 \mathrm{e}-5 \quad 94241.60 \mathrm{c} \quad 8.945 e-6 \quad 94242.60 \mathrm{c} \quad 4.689 e-6$

$92235.60 \mathrm{c} 2.897 \mathrm{e}-6 \quad 92238.60 \mathrm{c} 1.968 \mathrm{e}-3 \quad 8016.60 \mathrm{c} 4.348 \mathrm{e}-3$ $1001.60 \mathrm{c} 4.155 \mathrm{e}-2$ 6000.60c 4.287e-2 \$ Fuel Composition

$\mathrm{m} 2 \quad 1001.60 \mathrm{c} 5.712 \mathrm{e}-2 \quad 6000.60 \mathrm{c} 3.570 \mathrm{e}-2 \quad 8016.60 \mathrm{c} 1.428 \mathrm{e}-2$ $\$$ Plexiglas Reflector Composition

mit poly.01t

$\mathrm{m} 2 \mathrm{t}$ poly.01t 


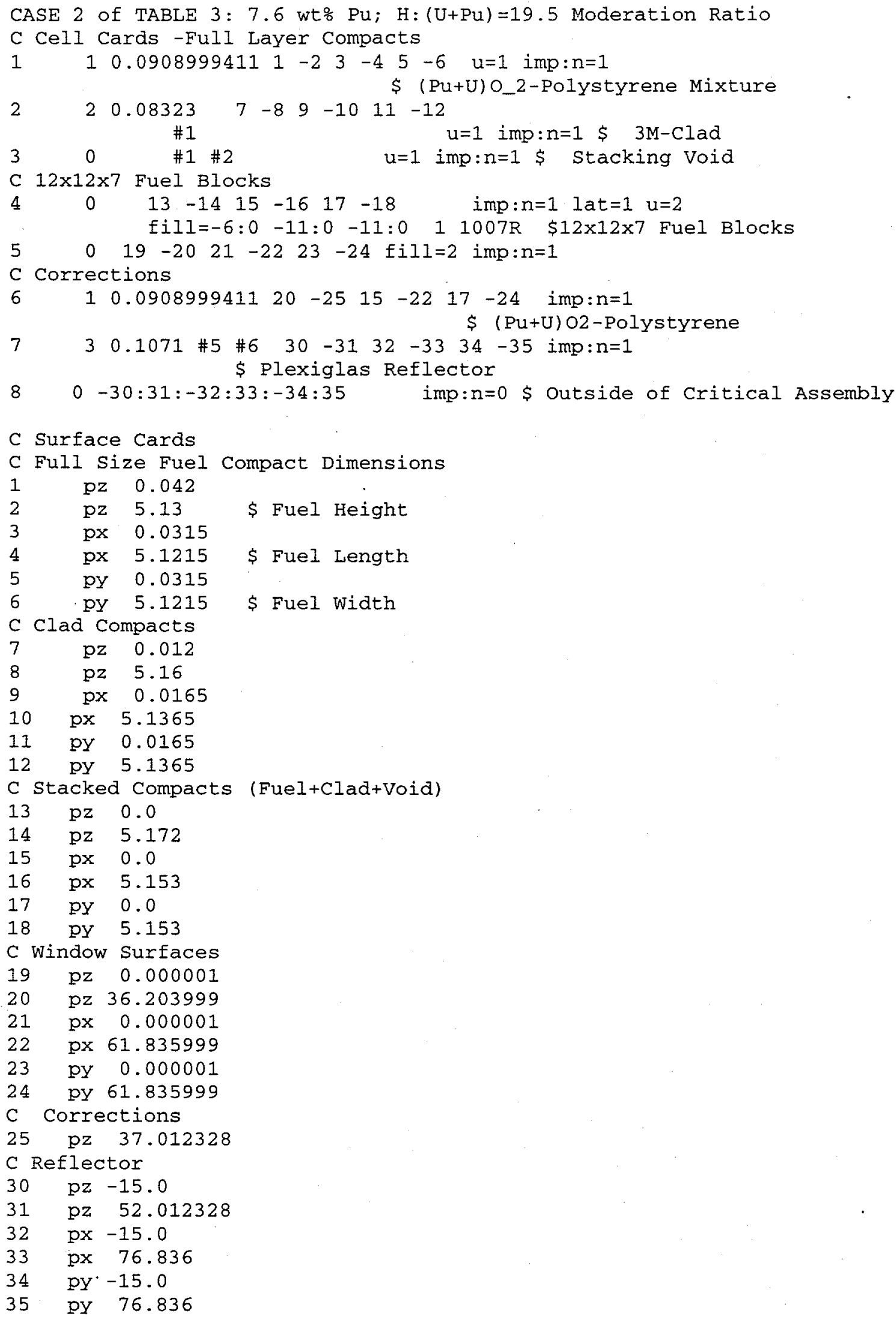


kcode 4000125225

ksrc 31. 31.18 .5

c print

$\mathrm{m} 1 \quad 95241.60 \mathrm{c} 3.766 \mathrm{e}-7 \quad 94238.60 \mathrm{c} \quad 9.535 \mathrm{e}-7 \quad 94239.60 \mathrm{c} 1.092 \mathrm{e}-4$

$94240.60 \mathrm{c} 3.688 \mathrm{e}-5 \quad 94241.60 \mathrm{c} 8.945 \mathrm{e}-6 \quad 94242.60 \mathrm{c} \quad 4.689 \mathrm{e}-6$

$92235.60 \mathrm{c} 2.897 \mathrm{e}-6 \quad 92238.60 \mathrm{c} 1.968 \mathrm{e}-3 \quad 8016.60 \mathrm{c} \quad 4.348 \mathrm{e}-3$

$1001.60 \mathrm{c} 4.155 \mathrm{e}-2 \quad 6000.60 \mathrm{c} 4.287 \mathrm{e}-2$ \$ Fuel Composition

m2 $1001.60 \mathrm{c} \quad 4.489 \mathrm{e}-2 \quad 6000.60 \mathrm{c} \quad 3.110 \mathrm{e}-2 \quad 17000.60 \mathrm{c} \quad 7.240 \mathrm{e}-3$

$\$$ Clad Composition

m3 $1001.60 \mathrm{c} \quad 5.712 \mathrm{e}-2 \quad 6000.60 \mathrm{c} 3.570 \mathrm{e}-2 \quad 8016.60 \mathrm{c} 1.428 \mathrm{e}-2$

$\$$ Plexiglas Reflector Composition

mit poly.01t

m2t poly.01t

m3t poly.01t 


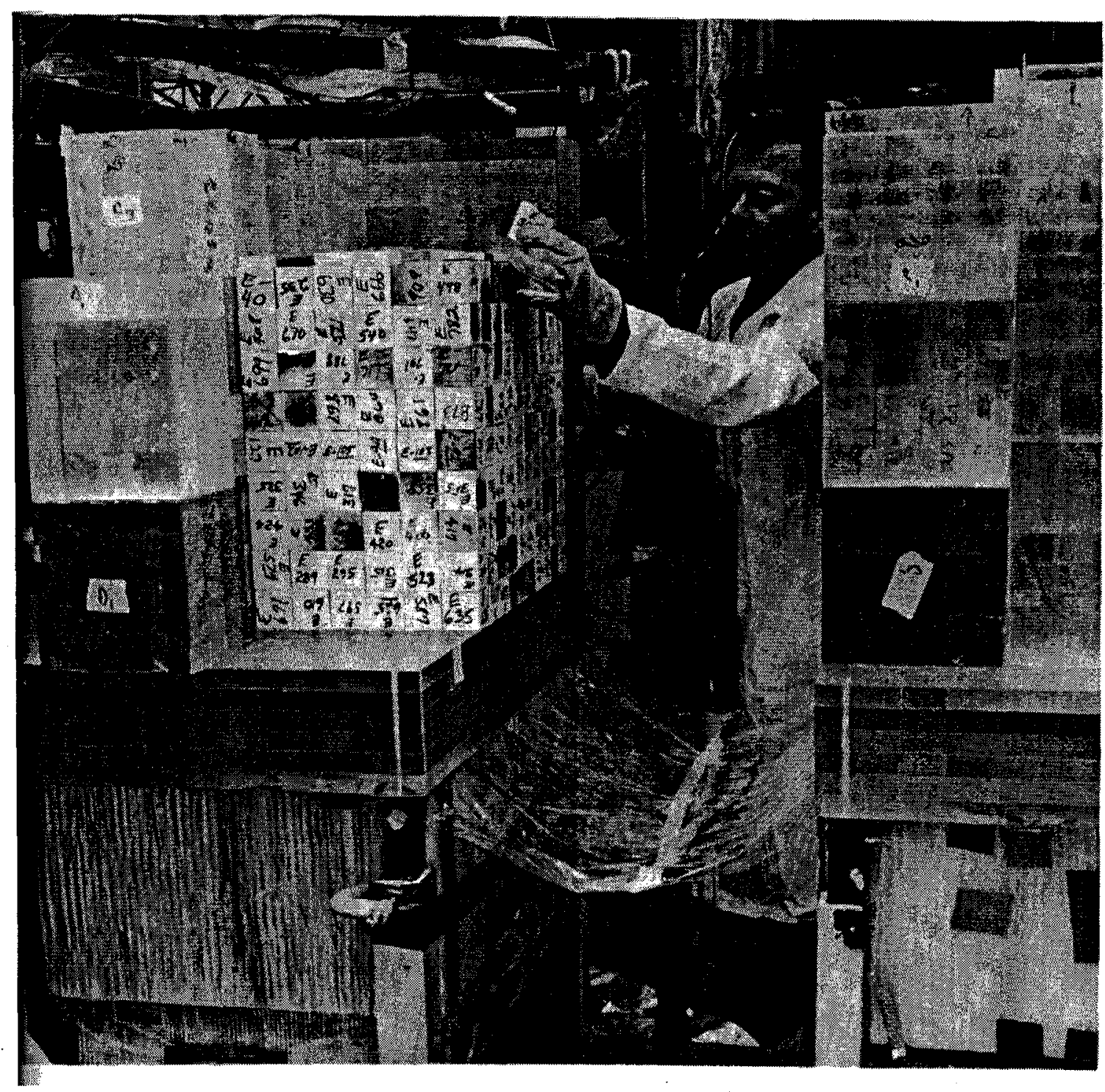

Figure 1. Remote split table with faces separated. 


\section{ORNL/SUB/99-XSZ175V-2}

\section{INTERNAL DISTRIBUTION}

$\begin{aligned} 1-5 . & \text { B. B. Bevard } \\ 6 . & \text { J. J. Carbajo } \\ 7 . & \text { E. D. Collins } \\ 8 . & \text { B. S. Cowell } \\ 9 . & \text { M. D. DeHart } \\ 10 . & \text { F. C. Difilippo } \\ 11 . & \text { R. J. Ellis } \\ 12-16 . & \text { J. C. Gehin } \\ 17 . & \text { S. R. Greene } \\ 18 . & \text { T. W. Horning } \\ 19 . & \text { D. T. Ingersoll }\end{aligned}$

\author{
20. H. T. Kerr \\ 21. M. A. Kuliasha \\ 22. G. E. Michaels \\ 23. B. D. Murphy \\ 24. D. L. Moses \\ 25. C. V. Parks \\ 26-30. R. T. Primm III \\ 31. C. C. Southmayd \\ 32. Central Research Library \\ 33-34. ORNL Laboratory Records (OSTI) \\ 35. ORNL Laboratory Records-RC
}

\section{EXTERNAL DISTRIBUTION}

36. N. Abdurrahman, College of Engineering, Dept. of Mechanical Engineering, University of Texas, Austin, Texas 78712

37. M. L. Adams, Department of Nuclear Engineering, Texas A\&M University, Zachry 129, College Station, TX 77843

38. H. Akkurt, College of Engineering, Dept. of Mechanical Engineering, University of Texas, Austin, Texas 78712

39. D. Alberstein, Los Alamos National Laboratory, MS-E502, P.O. Box 1663, Los Alamos, NM 87545

40. J. Baker, Office of Fissile Materials Disposition, U. S. Department of Energy, MD-3, 1000 Independence Avenue SW, Washington, DC 20585

41. J. B. Briggs, Idaho National Environmental and Engineering Laboratory, P.O. Box 1625-3855, Idaho Falls, ID 83415-3855

42. L. Holgate, Office of Fissile Materials Disposition, U. S. Department of Energy, MD-1/2, 1000 Independence Avenue SW, Washington, DC 20585

43. A. Caponiti, Office of Fissile Materials Disposition, U. S. Department of Energy, MD-3, 1000 Independence Avenue SW, Washington, DC 20585

44. K. Chidester, Los Alamos National Laboratory, MS-E502, P.O. Box 1663, Los Alamos, NM 87545

45. W. Danker, U. S. Department of Energy, MD-3, 1000 Independence Avenue SW, Washington, DC 20585

46. T. Gould, Lawrence Livermore National Laboratory, P.O. Box 808, MS-L186, Livermore, CA 94551

47. L. Jardine, Lawrence Livermore National Laboratory, P.O. Box 808, MS-L166, Livermore, CA 94551

48. Dr. Alexander Kalashnikov, Institute of Physics and Power Engineering, 1 Bondarenko Square, Obninsk, Kaluga Region, Russia 249020

49-53. D. E. Klein, Associate Vice Chancellor for Special Engineering Programs, The University of Texas System, 210 West Sixth Street, Austin, TX 78701

54. J. O. Nulton, Office of Fissile Materials Disposition, U.S. Department of Energy, MD-3, 1000 Independence Avenue SW, Washington, DC 20585

55. S. L. Passman, Sandia National Laboratories, 1401 Wilson Blvd., Suite 1050, Arlington, VA 22209

56-60. Dr. Alexander Pavlovitchev, Russian Research Center "Kurchatov Institute," Institute of Nuclear Reactors VVER Division, VVER Physics Department, 123182, Kurchatov Square, 1, Moscow, Russia

61. K. L. Peddicord, Associate Vice Chancellor, Texas A\&M University, 120 Zachry, College Station, TX 77843-3133

62. G. Radulescu, Framatom Cogema Fuels, 1261 Town Center Drive, MS-423, Las Vegas, Nevada 89143

63. W. D. Reece, Texas A\&M University, Department of Nuclear Engineering, Zachry 129, College Station, TX 77843-3133

64. P. T. Rhoads, Office of Fissile Materials Disposition, U.S. Department of Energy, MD-4, 1000 Independence Avenue SW, Washington, DC 20585

65. J. Thompson, Office of Fissile Materials Disposition, U.S. Department of Energy, MD-4, 1000 Independence Avenue SW, Washington, DC 20585

66. Fitz Trumble, Westinghouse Savannah River Company, Building 730R, Room 3402, WSRC, Aiken, SC 29808

67. M. Yavuz, 7201 Wood Hollow Drive, \#475, Austin, TX 78731 